\title{
Empreendedorismo Social: rumos e possibilidades para a economia solidária
}

A $11^{\text {a }}$ edição da Dignidade Re-Vista trará como tema: "Empreendedorismo Social: rumos e possibilidades para a economia solidária”.

Diretamente ligado ao processo do cooperativismo, as organizações e empresas estão pensando em novos procedimentos relacionados aos custos, investimentos, despesas e geração de impactos positivos, não somente na cadeia produtiva entre seus colaboradores, mas, também, para seus fornecedores e consumidores dos produtos e serviços. O empreendimento social busca romper a lógica dos modelos tradicionais de negócio. Segundo o Sebrae, a economia solidária tem como objetivo o impacto positivo em uma comunidade, ampliar as perspectivas de pessoas marginalizadas pela sociedade, gerar renda compartilhada e autonomia financeira para os indivíduos de classe baixa.

O tema voltado para empreendimento social aparentemente pode ser entendido como uma tendência nova no mundo dos negócios, contudo, já em 2006, o economista Bengali Muhammad Yunus recebeu o prêmio Nobel da Paz por desenvolver uma nova forma de negócio que tinha como objetivo promover o crédito como um dos Direitos Humanos, auxiliando as famílias pobres a se ajudarem a superar a pobreza. Diversos nomes sinônimos das práticas do empreendedorismo social têm se multiplicado e ganhado novas proporções na implementação nos setores da economia e divisão do trabalho.

Por conta do desencadeamento da pandemia causada pela Covid-19, o ano de 2020 tem se tornado um ano de superação e resiliência para todos os níveis econômicos de negócios; também haveria, em março deste ano, o Encontro Mundial para Repensar a Economia Global, organizado pelo Papa Francisco. Segundo o Papa, precisamos colocar em prática uma "economia diferente, que faz viver e não matar, incluir e não excluir, humanizar e não desumanizar, cuidar da Criação e não a depredar. Um evento que nos ajude a estar juntos e nos conhecer, e que nos leve a fazer um 'pacto' para mudar a atual economia e dar uma alma à economia do amanhã" (SEBRAE, 2010).

Por toda efervescência sobre a temática, e identificando que é um assunto debruçado na valorização dos Direitos Humanos, a Dignidade Re-Vista traz como tema da $11^{\mathrm{a}}$ edição o fomento da discussão "Empreendedorissmo Social: rumos e possibilidades para a economia solidária". 
FERREIRA, Leandro Assis. Editorial - Empreendedorismo Social: rumos e possibilidades para a economia solidária. Dignidade Re-Vista, v.6, n.11, dez 2020.

\section{DIGNIDADE \\ RE-VISTA} possibilidades para a economia solidária. Pastoral Universitária Anchieta PUC-RIO. 